\title{
The radiolarian age and petrographic composition of a block of the Lower Jurassic volcaniclastic breccia and chert of the Mamonia Complex, SW Cyprus
}

\author{
Nikita Bragin ${ }^{1}$, Galina Ledneva ${ }^{1}$, Liubov Bragina ${ }^{1}$, Efthymios Tsiolakis² Vasilis Symeou $^{2}$ and \\ Nikolaos Papadimitriou ${ }^{2}$
}

${ }^{1}$ Geological Institute of Russian Academy of Sciences, Moscow, 119017, Russia, ("corresponding author: bragin.n@mail.ru)

${ }^{2}$ Cyprus Geological Survey Department P.O.Box 24543, 1301 Lefkosia, Cyprus

doi: $10.4154 / g c .2022 .07$

Article history:

Received June 02, 2021

Revised manuscript accepted November 10, 2021 Available online February 22, 2022

Keywords: sedimentary-volcaniclastic breccia metavolcanics, Lower Jurassic, Radiolaria, Cyprus

\begin{abstract}
An exceptional exposure of volcaniclastic breccia intercalated with radiolarian cherts and limestones was studied which constitutes a unique block within the Upper Cretaceous Mamonia Mélange in the Akamas Peninsula of southwestern Cyprus. This breccia, represents the lower part of the sedimentary cover of the Upper Triassic Phasoula Formation volcanics. The breccia mainly consists of clasts of metabasalts, diabases, metagabbros, hyaloclastites and quartz-albite-chlorite-epidote aggregates, which have been metamorphosed at greenschist facies, and subordinate siltstones. The thin-bedded cherts intercalated between breccia levels, yielded radiolarian assemblages, which indicate an Early Jurassic age (Sinemurian to Pliensbachian) for the sequence.
\end{abstract}

\section{INTRODUCTION}

The geology of southwestern Cyprus is characterized by extensive occurrences of Mesozoic allochthonous rock assemblages that were grouped together as the Mamonia Complex (GASS, 1960; LAPIERRE, 1975; ROBERTSON \& WOODCOCK, 1979; SWARBRICK \& ROBERTSON, 1980; MALPAS et al., 1992). The Mamonia Complex is divided in two major sub-groups, the Ayios Photios Group and the Dhiarizos Group, including extensive zones of tectonic mélange known as the Mamonia Mélange (Fig. 1). The Ayios Photios Group (SWARBRICK \& ROBERTSON, 1980) consists of Upper Triassic to Upper Cretaceous sedimentary units (BRAGIN \& KRYLOV, 1996; 1999; BRAGIN et al., 2000; BRAGINA \& BRAGIN, 2016), while the Dhiarizos Group (SWARBRICK \& ROBERTSON, 1980) is composed of Upper Triassic to Lower Cretaceous basic volcanic rocks and their sedimentary cover. The Mamonia Mélange consists of a sedimentary matrix of highly tectonized siltstones and mudstones of the Ayios Photios Group, mixed with different-sized blocks from various lithologies of the Mamonia Complex and to a lesser extent from the Troodos Ophiolite (GEOLOGICAL SURVEY DEPARTMENT OF CYPRUS, 2008; 2015).

The age determination of the Mesozoic sedimentary sequences of the Mamonia Complex is estimated from the presence of radiolarian chert and cherty mudstone layers within these deposits, indicating that the radiolarian biostratigraphy is of significant importance for the dating of these deep-water lithologies, which lack other macrofossils or foraminifers.

This article presents new petrographic and palaeontological data from a sedimentary-volcaniclastic breccia block that presumably represents the lower part of the sedimentary cover of the Dhiarizos Group. This work represents the first time that this type of Lower Mesozoic sedimentary-volcaniclastic breccia, of southwestern Cyprus, is studied from a micropalaeontological/biostratigraphical perspective.

\section{GEOLOGICAL SETTING}

Two main Mesozoic rock complexes are widespread in southwestern Cyprus: the Troodos Ophiolite Complex and the Mamonia Complex (Fig. 2A). Both are allochthonous and form systems of nappes, the relationship between them is strictly tectonic. The Mesozoic complexes of Cyprus reflect the history of the southern branch of Neotethys. The Mamonia Complex represents the Upper Triassic to Cretaceous deposits and Upper Triassic volcanics of the northern margin of Gondwana, whereas the Troodos Complex constitute Cretaceous oceanic formations. Both complexes became juxtaposed in the Late Cretaceous with the development of the nappe system with chaotic assemblages (mélanges and olistostromes).

The Troodos Ophiolite Complex is a fully developed fragment of oceanic lithosphere that consists of lithologies ranging from upper mantle harzburgites to pillow lavas, overlain by umbers (hydrothermal sediments) with radiolarian cherts of the upper Turonian to uppermost Santonian Perapedhi Formation (WILSON, 1959; SWARBRICK \& ROBERTSON, 1980; BLOME \& IRWIN, 1985; BRAGINA \& BRAGIN, 1996; BRAGINA, 2012; 2016). The latter are locally capped by a sedimentary sequence consisting of Campanian to middle Maastrichtian bentonitic clays and volcaniclastic sandstones and siltstones of the Kannaviou Formation (ROBERTSON \& HUDSON, 1974; ROBERTSON, 1977).

The Mesozoic lithologies of the Mamonia Complex are mainly grouped into the Ayios Photios Group (sedimentary) and the Dhiarizos Group (volcano-sedimentary), (ROBERTSON \& WOODCOCK, 1979; SWARBRICK \& ROBERTSON, 1980), which are subdivided into a number of sub-units (Fig. 1). The Ayios Photios Group consists of the following sub-units: the Vlampouros Formation (Upper Triassic siliciclastics and micritic limestones with minor chert interlayers) (SWARBRICK \& ROBERTSON, 1980; BRAGIN \& KRYLOV, 1996; TORLEY \& ROBERTSON, 2018) and the Episkopi Formation (Middle Jurassic to 


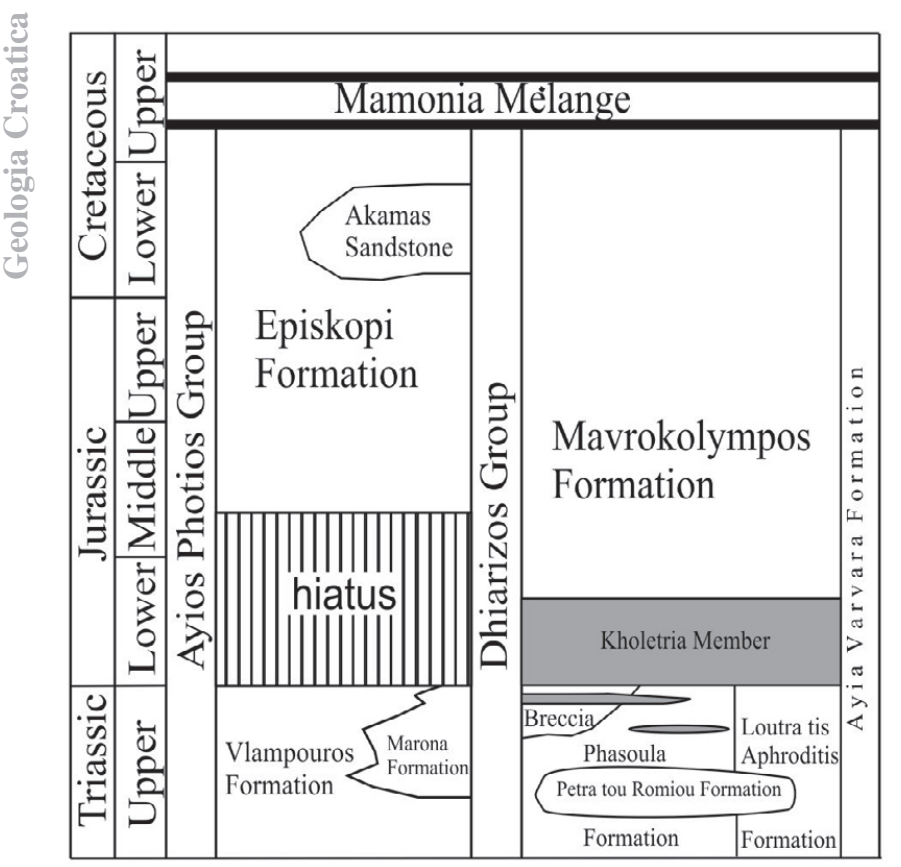

Figure 1. Generalized chart of the stratigraphy of the Mamonia Complex. The grey area shows the Kholetria Member within and above the Phasoula Formation. For other lithologies and references see text.

middle Cretaceous, Albian-Turonian, alternating layers of cherts, mudstones, limestones, sandstones, siltstones and clays) (SWARBRICK \& ROBERTSON, 1980; BRAGIN \& KRYLOV, 1999; BRAGIN et al., 2000). The thick Lower Cretaceous sandstones within the Episkopi Formation are referred to as the Aka- mas Member or the Akamas Sandstone (SWARBRICK \& ROBERTSON, 1980). Several authors in previous studies have included within this group another sub-unit, referred to as the Marona Formation to describe blocks of Upper Triassic hemipelagic limestones (SWARBRICK \& ROBERTSON, 1980; TORLEY \& ROBERTSON, 2018).

The Dhiarizos Group consists of the following sub-units: the Phasoula Formation (Upper Triassic basic volcanics with interlayers of limestones and cherts) (SWARBRICK \& ROBERTSON, 1980; BRAGIN, 2007; 2010), the Loutra tis Aphroditis Formation (Upper Triassic lava breccias and volcaniclastic breccias with interlayers of volcaniclastic siltstones and radiolarian mudstones) (SWARBRICK \& ROBERTSON, 1980), the Petra tou Romiou Formation (detached blocks of Upper Triassic reefal limestones) (HENSON et al., 1949; SWARBRICK \& ROBERTSON, 1980; MARTINI et al., 2009), and the Mavrokolympos Formation (Jurassic to Cretaceous alternating layers of limestones, cherts, mudstones, siltstones and calcilutites) (SWARBRICK \& ROBERTSON, 1980). The sedimentary interlayers within and above the Phasoula and Loutra tis Aphroditis formations are referred to as the Kholetria Member and are represented by chert-limestone alternations (SWARBRICK \& ROBERTSON, 1980). Furthermore, the greenschist- to amphibolite-facies metamorphic rocks are termed the Ayia Varvara Formation (metasediments and metavolcanics of various Dhiarizos lithologies, metamorphosed during the Cretaceous) (MALPAS et al., 1992; CHAN et al., 2007; 2008).

For the purposes of this study, field work was conducted in the southwestern part of the Akamas Peninsula (Fig. 2). This area is characterized by the extensive distribution of the Ayios Photios Group lithologies and the Mamonia Mélange. Furthermore, seve-

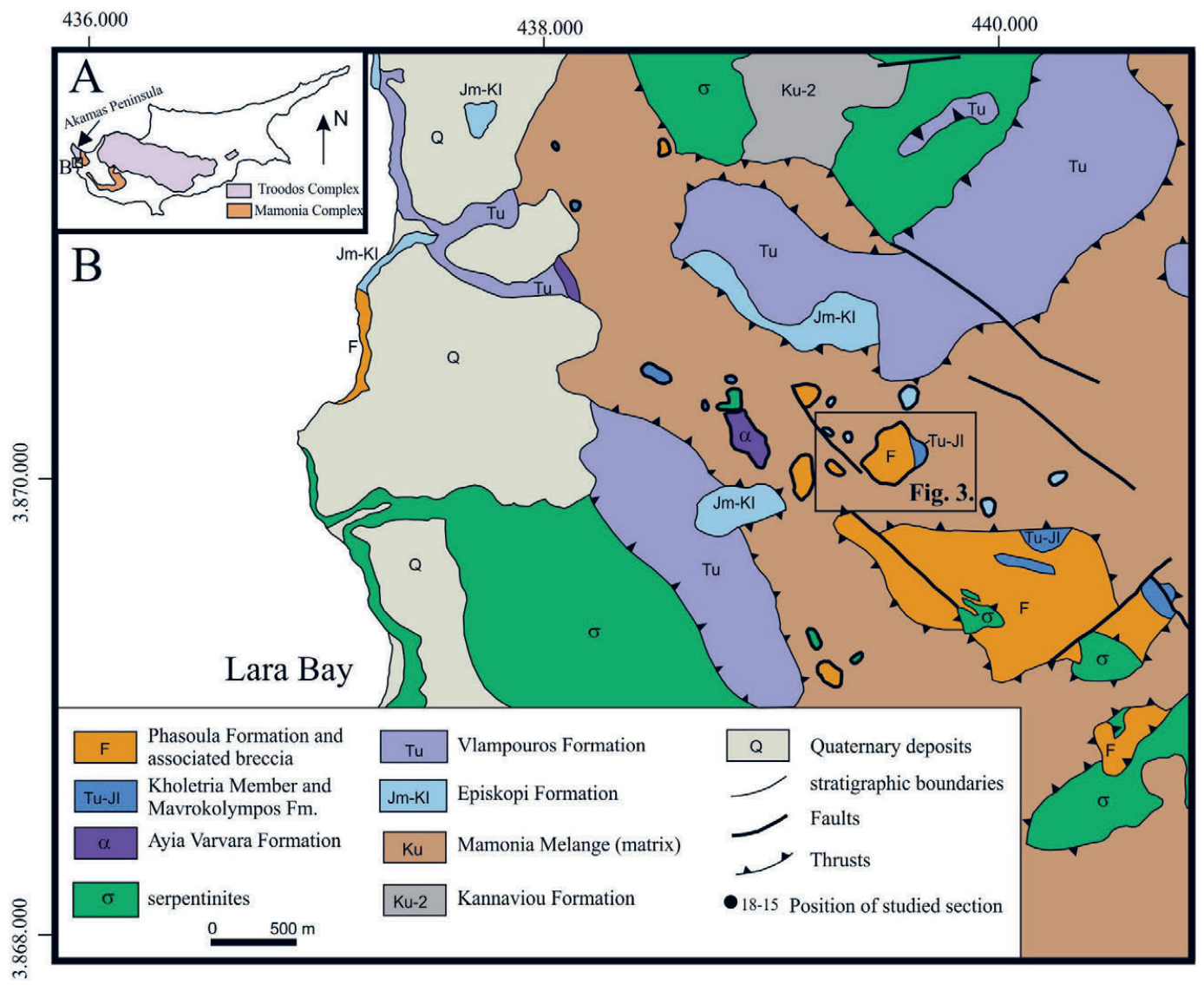

Figure 2. A - position of the study area in western Cyprus. B - Generalized geological map of the area east of Lara Bay (Akamas Peninsula, Cyprus) (GEOLOGICAL SURVEY DEPARTMENT OF CYPRUS, 2015). 


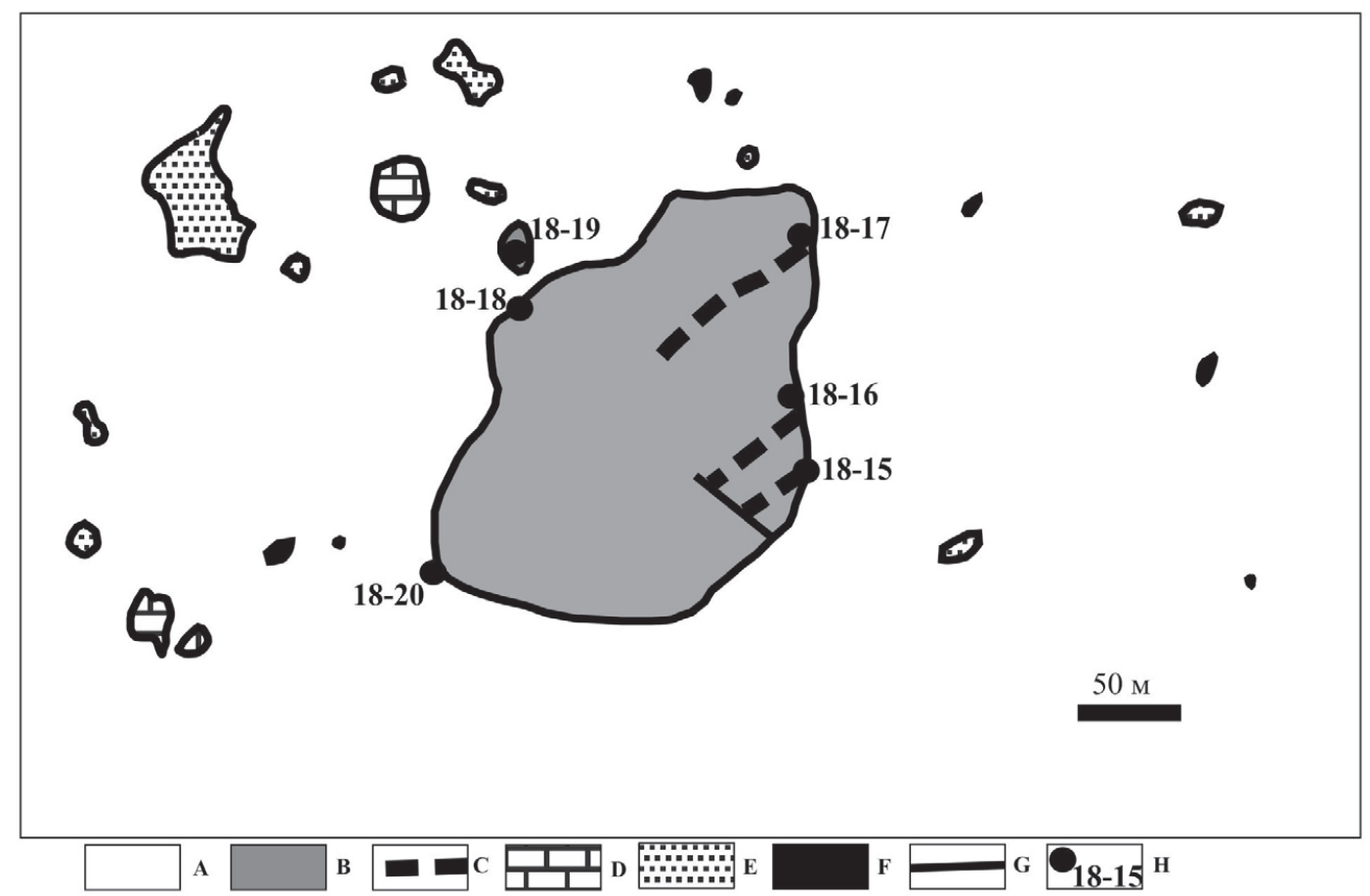

Figure 3. Detailed map of the block of diabase-gabbro breccia. A - matrix of the Mamonia Mélange; B - diabase-gabbro breccia; C - beds of limestone and radiolarian chert within the breccia; D - blocks of the Petra tou Romiou limestone; E- blocks of the Akamas sandstone; F - blocks of basic volcanics; $\mathbf{G}$ - fault within a block of diabase-gabbro breccia; $\mathbf{H}$ - positions of sampling and studying points.

ral big blocks of the Dhiarizos Group (mainly the Phasoula Formation) are also observed within the Mamonia Mélange. These blocks are mainly composed of basic volcanics commonly with interbeds of limestone and radiolarian chert. One of these blocks is composed of sedimentary-volcaniclastic breccia consisting mainly of fragments of basalts, diabases and gabbro, with interlayers of limestones and cherts that yield abundant radiolarian assemblages.

This roughly rounded block is located $2.5 \mathrm{~km}$ east-northeast of the northern Lara Bay (Fig. 2) and has an extent of 270 x 200 $\mathrm{m}$, with an elongated axis along a SW - NE direction (Fig. 3, Fig. 4A, B). The studied breccia block is in tectonic contact with the surrounding matrix of the Mamonia Mélange, that yields numerous small blocks of Lower Cretaceous Akamas Sandstone of the Episkopi Formation (SWARBRICK \& ROBERTSON, 1980) (Fig. 4C), Upper Triassic limestones of the Petra tou Romiou Formation or the Kholetria Member (SWARBRICK \& ROBERTSON, 1980), as well as basic volcanics of the Upper Triassic Phasoula Formation. The matrix of the mélange consists of reddish-grey to brownish-grey mudstones and siltstones. Furthermore, another, smaller block of similar breccia was identified near the NW boundary of the studied breccia block (Fig. 3, sampling location 18-19).

From the detailed survey of the large breccia block, from the northwestern boundary (point 18-18, coordinates $34^{\circ} 58^{\prime} 22,4^{\prime \prime}$ $\mathrm{N}, 32^{\circ} 20^{\prime} 13,4^{\prime \prime}$ E) towards its southern edge (point 18-15, coordinates $34^{\circ} 58^{\prime} 17,5^{\prime \prime} \mathrm{N}, 32^{\circ} 20^{\prime}$ 19,9” E) (Fig. 3, 4, 5, 6), various individual units of the block were recognized and described:

1. Greenish-grey hard cemented breccia mainly consisting of small (3-5 up to $15-20 \mathrm{~cm}$ in size) diabase and subordinate metagabbro clasts in a coarse-grained to gravelly matrix of the same composition. The thickness of the unit is $50 \mathrm{~m}$.
2. Greenish-grey and reddish-brown hard cemented breccia of metabasalt, diabase and metagabbro clasts with rare small fragments of red recrystallized limestone in a coarse-grained to gravelly matrix of metabasalt, diabase and metagabbro. Lenses (1-2 $\mathrm{m}$ thick) of breccia within a pinkish matrix of highly brecciated limestone, occur in the upper part of the unit. The thickness of the unit is $100 \mathrm{~m}$.

3. Pink to greenish-brown hard cemented breccia of diabase and metabasalt clasts within a matrix of highly brecciated pink to white limestone (Fig. 4F). The thickness of the unit is $4 \mathrm{~m}$.

4. Greenish-grey hard cemented breccia with lenses $(1,5 \mathrm{~m}$ thick) of breccia within a matrix of highly brecciated pink to white limestone (Fig. 4E). The thickness of the unit is $20 \mathrm{~m}$.

5. White to pink, hard, thin-bedded recrystallized limestones with calcite veins (Fig. 5F). The thickness of the unit is $2 \mathrm{~m}$.

6. Greenish-grey hard cemented breccia consisting of metabasalt, diabase and metagabbro fragments and blocks (Fig. 4G, H) in a coarse-grained to gravelly matrix of the same composition. The thickness of the unit is $5 \mathrm{~m}$.

7. Brick-red and crimson-red, thin-bedded radiolarian cherts (Fig. 5D) with interbeds (0,5 - $1 \mathrm{~m})$ of pink and white hard recrystallized limestones (Fig. 5E). The thickness of the unit is $20 \mathrm{~m}$.

8. Greenish-grey to reddish-brown, hard cemented breccia consisting of diabase and metagabbro fragments and blocks as well as rare fragments of siltstones in a coarsegrained to gravelly matrix of the metabasalt, metagabbro and diabases. The thickness of the unit is $5 \mathrm{~m}$.

9. Brick-red, thin-bedded radiolarian cherts intercalated with red cherty mudstones. Interbeds (up to $1 \mathrm{~m}$ ) of dark- 


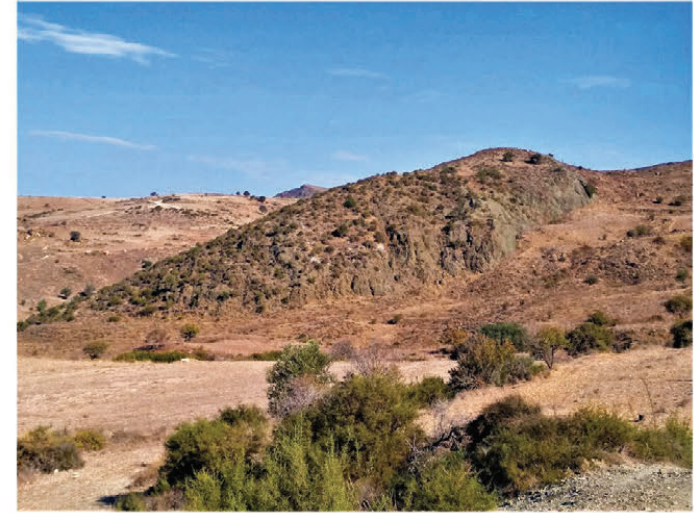

A

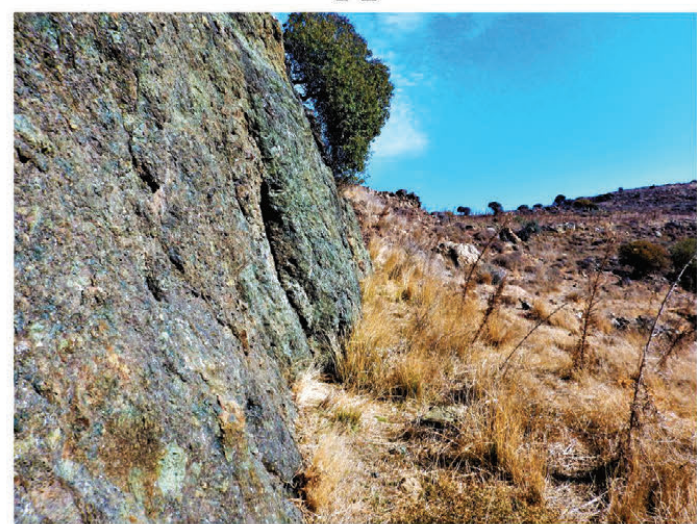

C

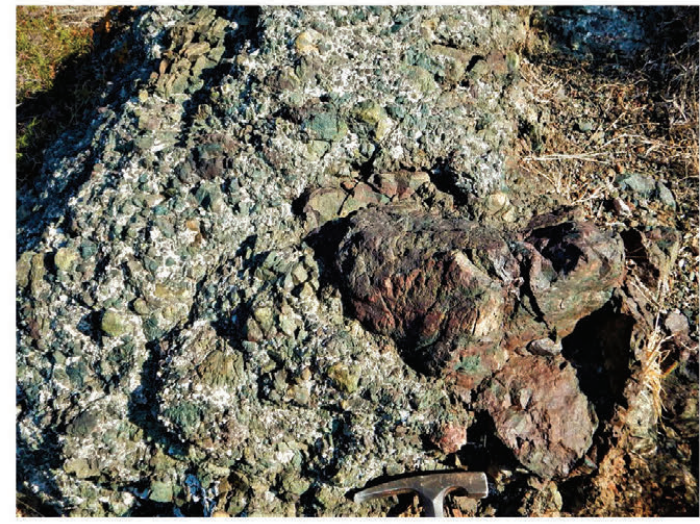

E

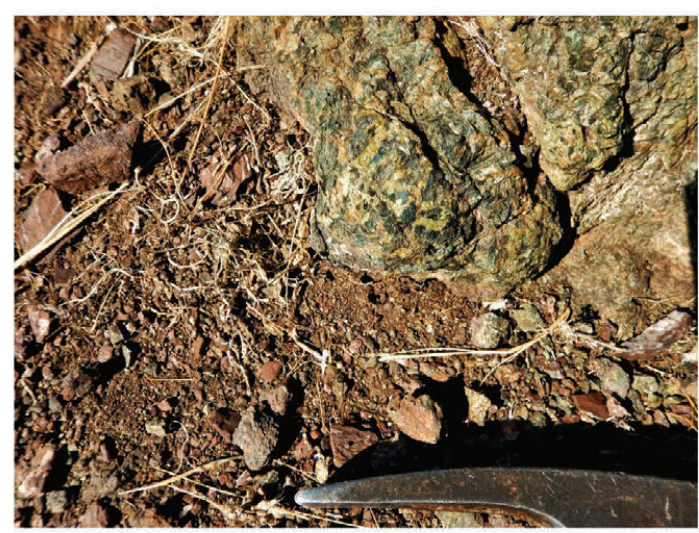

G

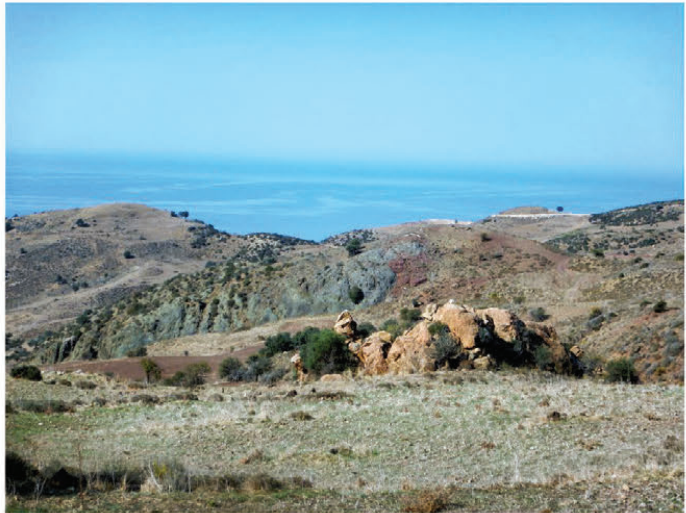

B

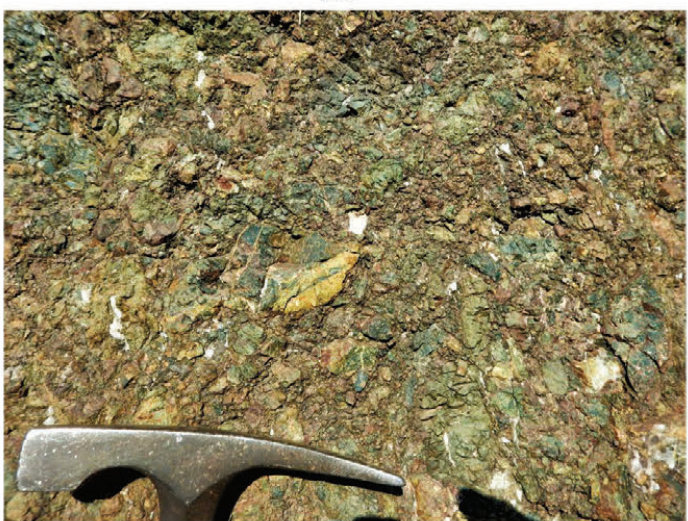

D

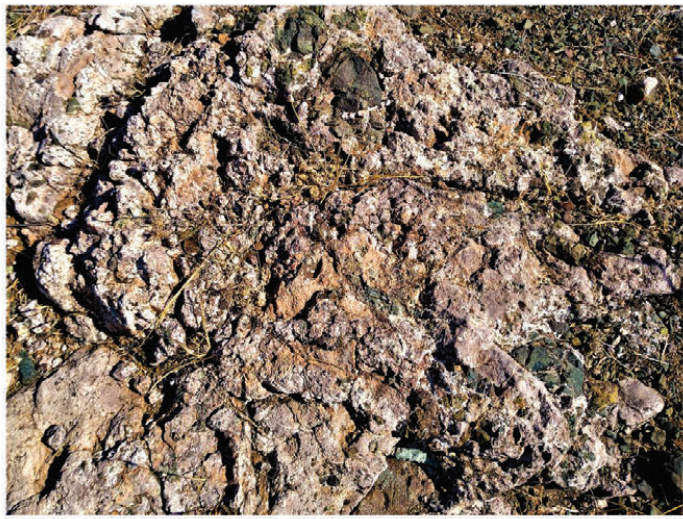

F

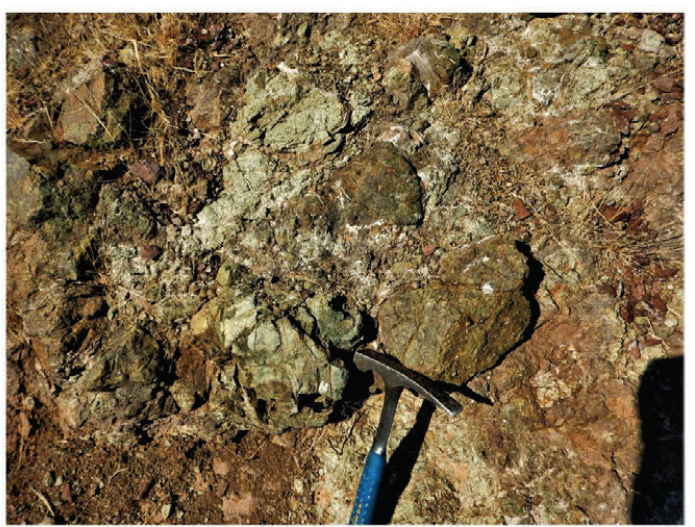

$\mathrm{H}$

Figure 4. Volcaniclastic breccia of the Akamas Peninsula. Outcrops of breccia. A - Block of the breccia, view from the south; B - Same block, view from the east; C - Contact between the breccia (left) and the Mamonia Mélange (right, with scattered blocks of Akamas Sandstone); D - breccia composed of small diabase and metabasalt clasts in a volcaniclastic matrix (unit 10); $\mathbf{E}$ - breccia with carbonate (calcite) matrix (unit 4); F - breccia with well-developed carbonate matrix represented by pink micritic limestone (unit 3); $\mathbf{G}$ - block of metagabbro (unit 6); $\mathbf{H}$ - blocks of diabase (unit 6). 


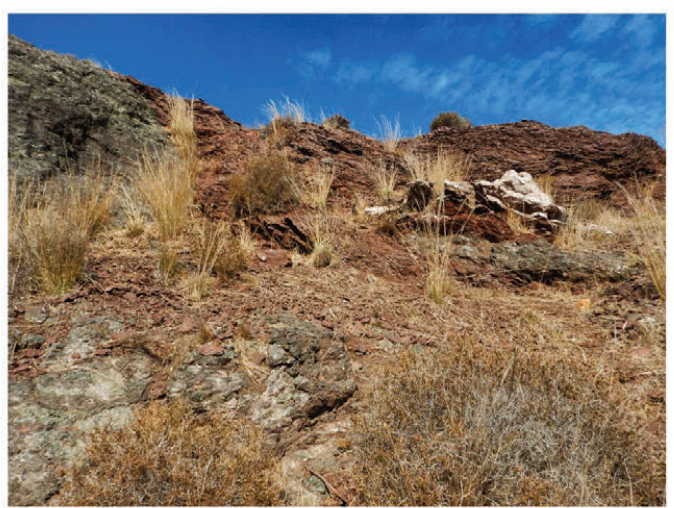

A

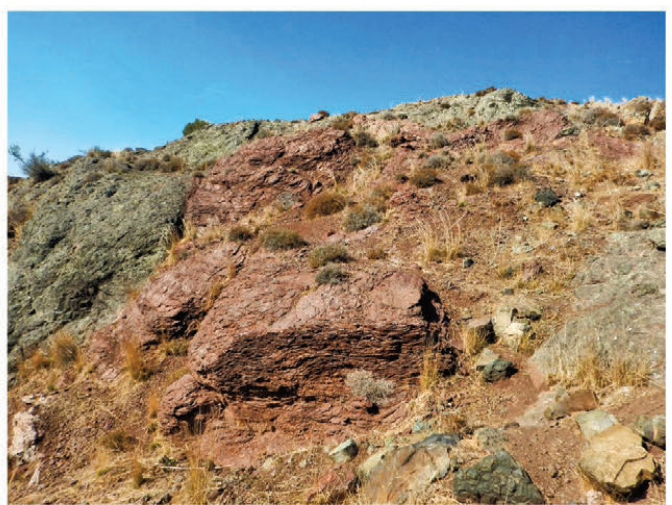

C

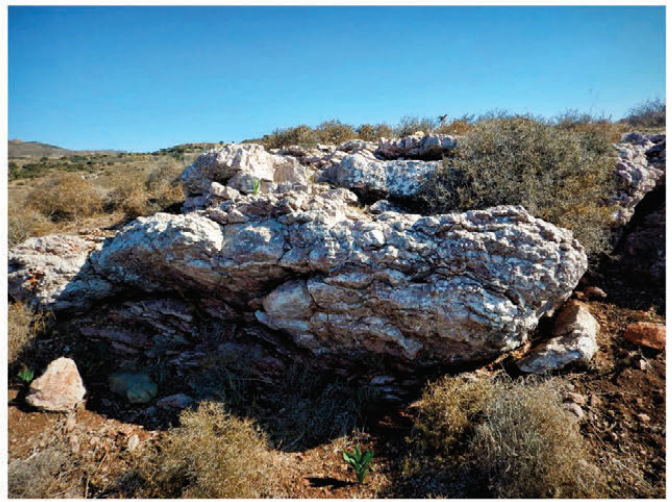

E

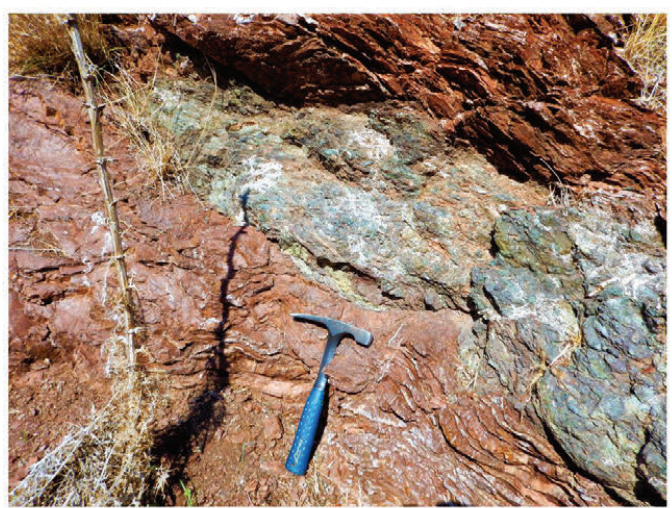

B

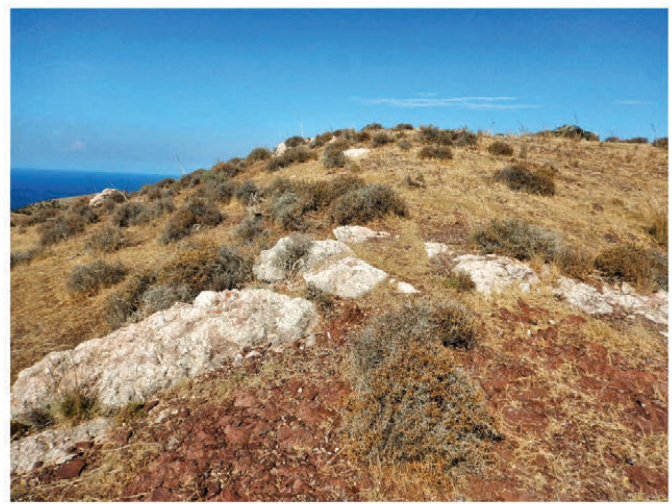

D

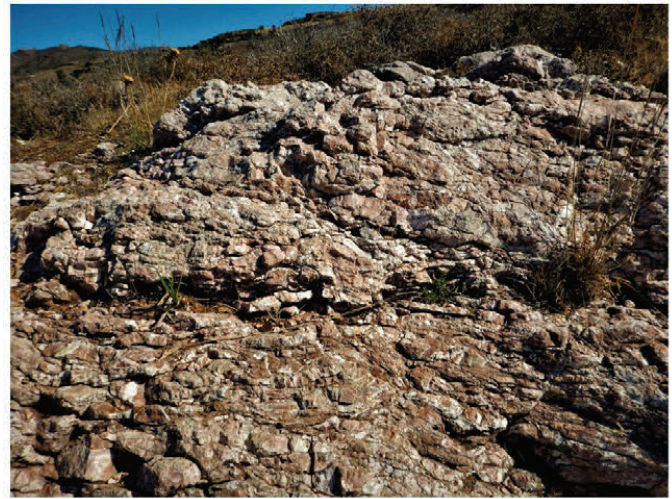

F

Figure 5. Volcaniclastic breccia of the Akamas Peninsula. Outcrops of sedimentary units (chert and limestone) between breccia. A - Red radiolarian cherts and white limestones in direct contact with breccia (units 9 and 10); B - Sedimentary contact between breccia and radiolarian chert. Small lense of breccia within radiolarian cherts (unit 9); C - radiolarian cherts, a fault is visible in the left side of the photograph (unit 9); D - radiolarian cherts and bed of limestone (unit 7); E - strongly brecciated white to pink limestone (unit 7); F - thin-bedded tectonized and brecciated pink to white limestone (unit 5).

greenish-grey breccia with fragments of metabasalt and metagabbro and lenses of pink recrystallized brecciated limestone are observed in the middle part of this unit. The contact between the chert and breccia layers is clearly sedimentary (Fig. 5A-C). The thickness of the unit is $5 \mathrm{~m}$.

10. Dark-greenish-grey hard cemented breccia composed of unsorted diabase and metabasalt fragments in a coarsegrained to gravelly matrix of the same composition (Fig. 4D). The thickness of the unit is $6 \mathrm{~m}$.

It is herein assumed that this fragmentary section is the lower part of the sedimentary cover of the Upper Triassic volcanics of the Dhiarizos Group, which consists of breccia, while the upper part of the succession is characterized by the presence of limestone and radiolarian chert layers that become more and more abundant towards the top.

\section{MATERIALS AND METHODS}

Twenty-five samples of various rock types including metavolcanics, limestones and cherts were collected during fieldwork in 2018 and 2019. The petrography of the acquired rock samples was studied in standard thin-sections using a light microscope Olympus BS51. Radiolarians were extracted from chert samples using diluted $(5 \%)$ hydrofluoric acid (HF) for twelve (12) hours and the residues were rinsed with water and dried. The residues were studied using a light microscope LOMO-MBS-10. The microfos- 


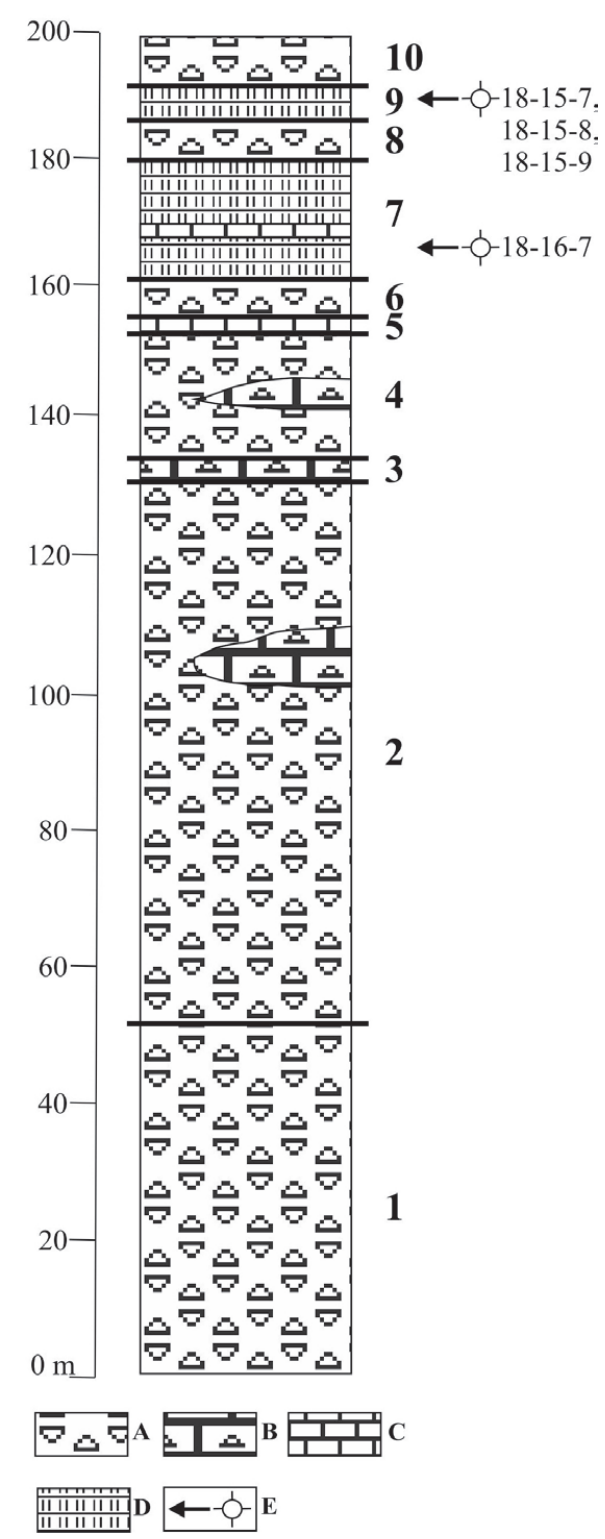

Figure 6. Stratigraphic column of volcaniclastic breccia with interbeds of limestones and cherts. A - breccia with volcaniclastic matrix; B - breccia with carbonate matrix; $\mathrm{C}$ - limestone; $\mathrm{D}$ - radiolarian chert; $\mathrm{E}$ - position of samples with radiolarians and their numbers. Numbers of units according to the description are shown to the right of the column.

sils were collected, mounted, studied in detail and photographed with scanning electron microscopes: TESCAN 2300 in the Geological Institute RAS, Moscow, and TESCAN VEGA-II XMU in the Palaeontological Institute RAS, Moscow. Thin sections and radiolarian assemblages are stored in the Geological Institute RAS, Moscow, Russia.

\section{PETROGRAPHY}

\subsection{Breccia with carbonate matrix}

The breccia consists of metabasalt, diabase and metagabbro blocks and clasts that are irregularly shaped, sub-angular and poorly sorted. These rock fragments vary from a few centimetres to $10-15$, rarely $20-30 \mathrm{~cm}$ in size. The matrix is represented by micritic limestone or recrystallized calcite.

\subsubsection{Breccia clasts}

Metabasalts are represented by amygdaloidal aphyric, plagioclase- and clinopyroxene-plagioclase porphyric varieties (Fig.
7A, B, 8A, B). Phenocrysts of clinopyroxene are represented by short-prismatic crystals (0.4-0.9 mm) and are partly replaced by amphibole. Phenocrysts of plagioclase are tabular and often elongated tabular zoned crystals $(0.2 \mathrm{~mm})$; plagioclase is completely altered pseudomorphs of albite, epidote group mineral and chlorite creating a very fine-grained aggregate. The groundmass exhibits hyalopilitic and intersertal textures. The intersertal groundmass is composed of altered plagioclase, altered pyroxene and opaque minerals; the hyalopilitic groundmass is composed of elongated, needle-shaped, often skeletal plagioclase and altered glass replaced by a black opaque substance.

Diabase (Fig. 7C) is composed of pseudomorphs after the alteration of plagioclase and pyroxene crystals, Fe-Ti oxides, quartz and micrographic intergrowths of quartz with feldspar. Plagioclase pseudomorphs are nearly euhedral in form, elongated tabular grains of a microcrystalline aggregate of epidote, colourless chlorite and albite in cores or rims. Pyroxene pseudomorphs are nearly euhedral and anhedral grains, represented by light-green to colourless amphibole with tiny inclusions of titanite. Fe-Ti oxides, which are abundant in the rock, comprise euhedral crystals with lacy edges. Minor quartz $(<1 \%)$ and its intergrowths with feldspar $(<1 \%)$ fill interstices. The rock texture is doleritic.

\subsubsection{Carbonate matrix}

The matrix is represented mainly by pink to white micritic limestone which is often strongly brecciated and cut by calcite veins (Fig. 8A, B). This matrix yields small non-sorted clasts of metabasalts and chlorite (formed supposedly after volcanic glass). Sometimes, the matrix is represented by highly recrystallized calcite. There is no visible layering of the matrix. Rare epidote group minerals are present in the carbonate matrix between clasts (Fig. 7B).

\subsection{Breccia with sandstone-gravel matrix}

This type of breccia is composed of metabasalt, diabase and metagabbro blocks, altered volcanic glass, quartz-albite-chlorite-epidote aggregates and rarely siltstone clasts. Blocks and clasts are irregularly shaped, sub-rounded and poorly sorted rock fragments from predominantly few centimetres up to $20-30 \mathrm{~cm}$ in size. The matrix is represented by sandstone-gravel that has the same composition with the large (both rock and mineral debris) clasts.

\section{Breccia clasts}

Metabasalts and diabase are represented by the same lithologies as clasts of the breccia with carbonate matrix.

Metagabbro (Fig. 7D) is composed of clinopyroxene, pseudomorphs after the alteration of plagioclase and an accessory opaque mineral. Clinopyroxene is preserved only in relicts and is largely replaced by green to light-yellow amphibole with lamellae of an opaque mineral ( $<100 \mu \mathrm{m}$ in size) and chlorite with interference in a blue colour. Plagioclase pseudomorphs form euhedral tabular grains, composed of a microcrystalline aggregate of albite, an epidote group mineral and chlorite. The opaque mineral is anhedral. Metagabbro is a fine- to medium-grained rock exhibiting a primary hypidiomorphic-granular texture.

Some clasts exhibit no primary textures. Intensively fractured clasts of presumably altered volcanic glass (Fig. 7E) consist of pale-green and colourless chlorite with minor hydrogarnet and fine- to medium-grained aggregates of quartz, albitite, epidote group mineral and chlorite which are produced from an unidentified rock. 

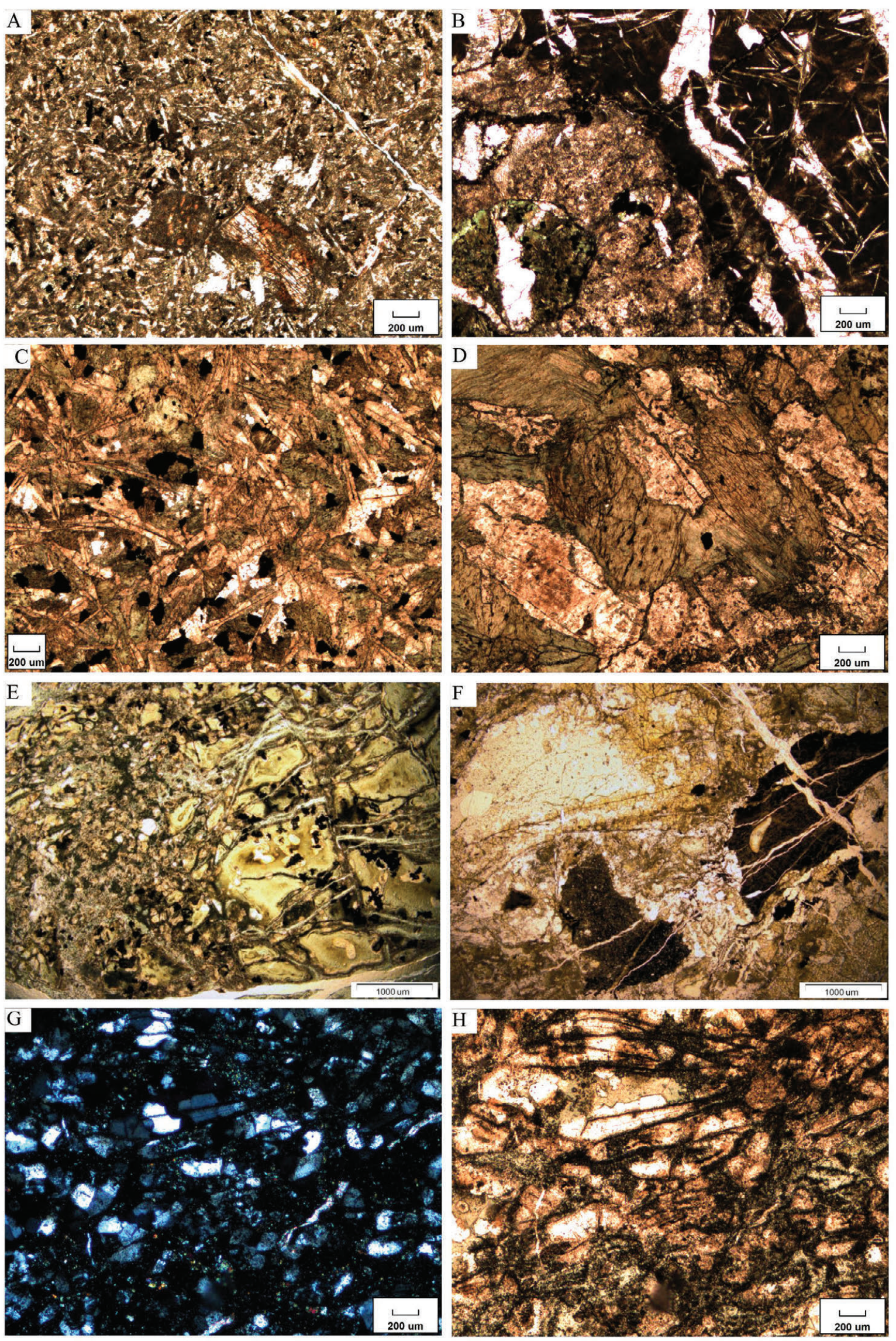

Figure 7. Clasts typical of breccia. A - plagioclase-pyroxene porphyric basalts with intersertal groundmass (sample 18-17-6, unit 4); B - clasts of amygdaloidal aphyric basalt with a hyalopilitic groundmass and chlorite presumably after volcanic glass in carbonate matrix (sample 18-17-3, unit 4); C - diabase (metadolerite), enriched by ore minerals (sample 18-16-2, unit 8); D - metagabbro with plagioclase replaced by albite, zoisite and chlorite, and with clinopyroxene replaced by amphibole (sample 18-20-2, unit 1); E - fractured clast of chlorite with minor hydrogarnet presumably after volcanic glass in sandstone matrix dominated by quartz and plagioclase (sample 18-15-2, unit 10); F - clasts of siltstone and aggregate of quartz, albite, epidote group mineral and chlorite (sample 18-15-3, unit 10); G - detail of siltstone clast, polarized light (sample 18-15-3, unit 10); $\mathbf{H}$ - detail of siltstone clast (sample 18-15-3, unit 10). 

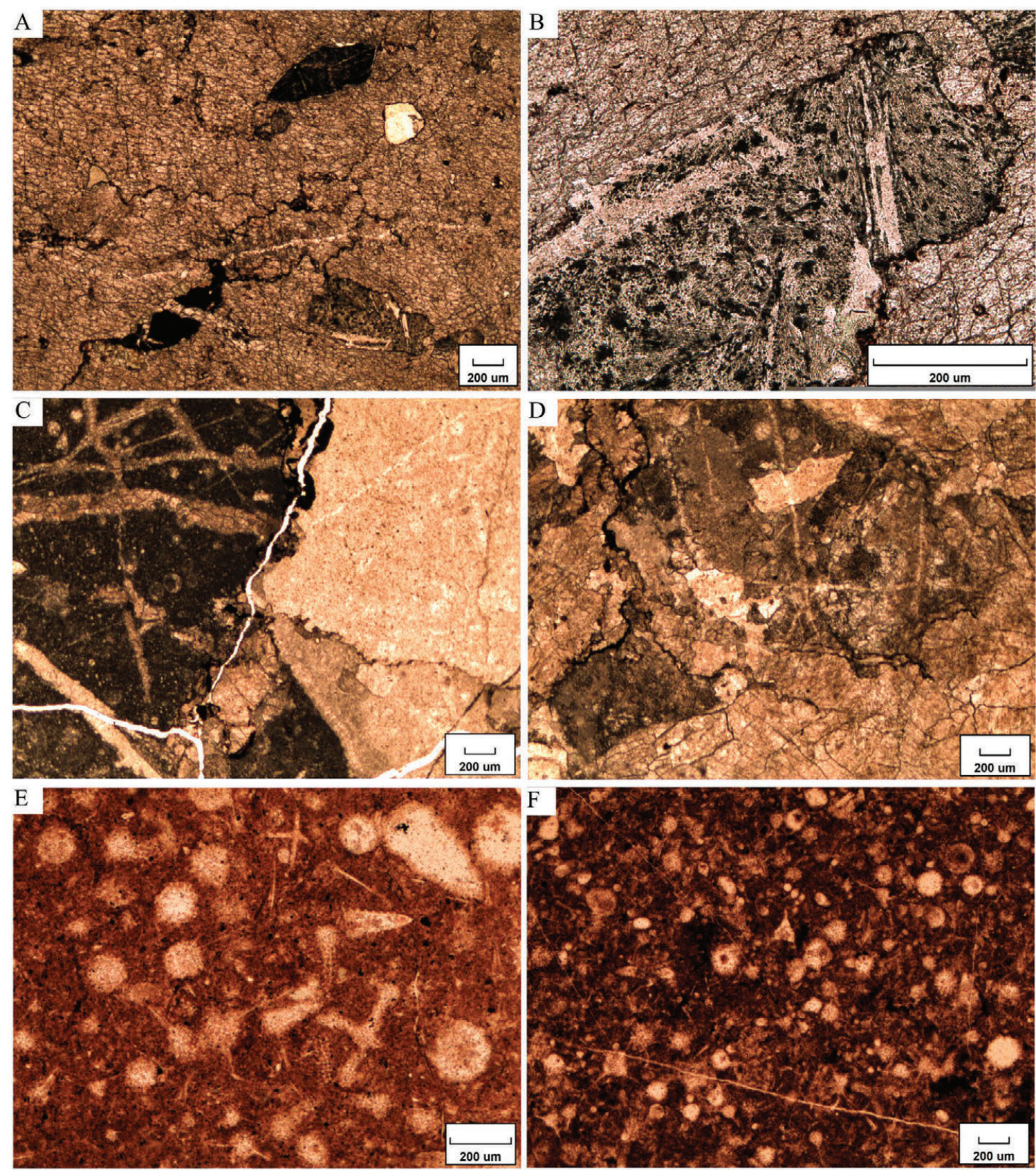

Figure 8. Sedimentary rocks intercalated with breccia. A - brecciated limestone with rare clasts of aphyric and plagioclase porphyry metabasalts, and chlorite supposedly after volcanic glass. Fractures filled with calcite cut both matrix and clasts (sample 18-17-5, unit 4); B - limestone with clast of plagioclase porphyry metabasalt with intersertal groundmass (sample 18-17-5, unit 4); C, D - brecciated micritic limestones with relics of radiolarians (sample 18-15-1, unit 9); E - red radiolarian chert with moderately preserved radiolarians (sample 18-15-7, unit 9); F - dark-red radiolarian chert with abundant, moderately to poorly preserved radiolarians (sample 18-6-6, unit 7).

Siltstone clasts (sample 18-15-2, unit 10, Fig. 7F-H) are composed of quartz and feldspar (albite). The supporting matrix is composed of chlorite and an epidote group mineral. Thin fractures are filled by carbonate minerals.

\section{Sandstone-gravel matrix}

Sandstone-gravel matrix is represented by the same lithologies as in the blocks and clasts. The matrix exhibits no layering or sorting. Occasional veins of calcite are present.

\subsection{Limestone and radiolarian chert beds and lenses within the breccia succession}

Limestones and radiolarian cherts form interbeds and lenses within the breccia. Limestones are represented by micrites which are commonly brecciated, and sometimes contain recrystallized radiolarian remains. Stylolites and fractures filled by calcite are common; these fractures are commonly confined to limestone clasts (Fig. 8C, D).

Red radiolarian cherts usually yield abundant, moderately, to poorly preserved radiolarian assemblages. Fractures are filled by quartz (Fig. 8E, F).

\section{RADIOLARIAN ASSEMBLAGE AND AGE OF BRECCIA}

Abundant radiolarians are present in the chert beds of the upper part of the studied section (Plate 1, 2, localities 18-15 and 18-16). The systematic composition of the radiolarian assemblages re- 


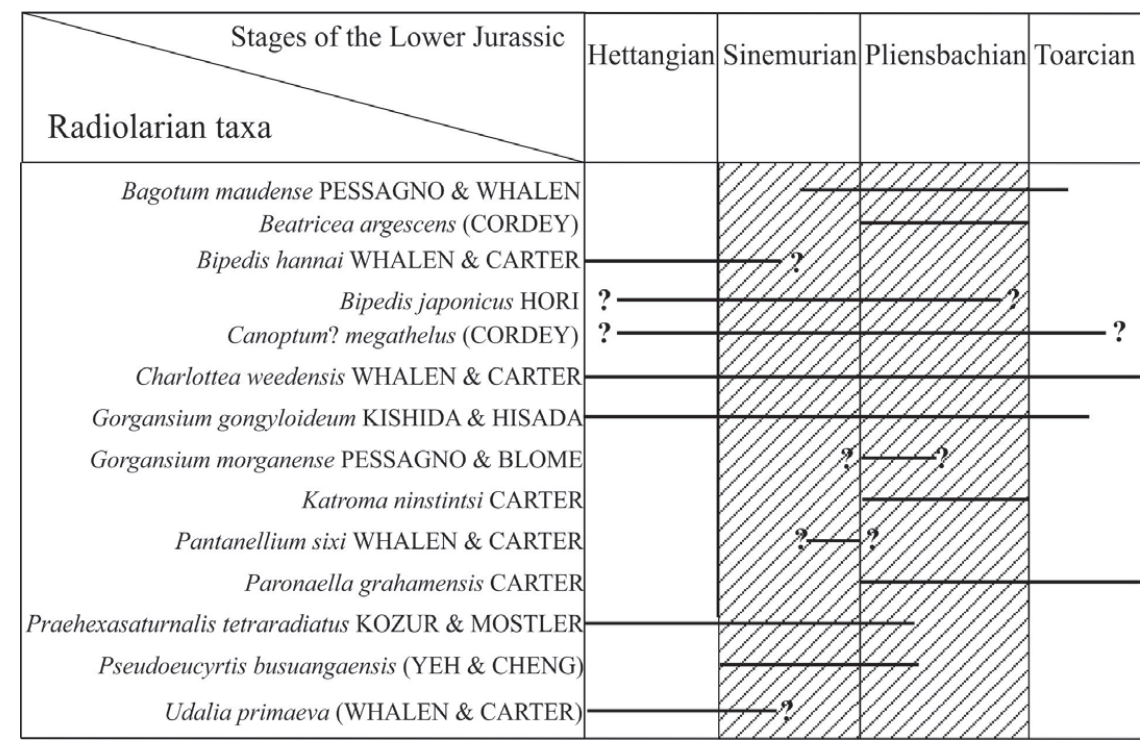

Figure 9. Stratigraphic ranges of selected radiolarian taxa and proposed dating of the breccia unit.

Table 1. Taxonomic composition of studied samples of radiolarian cherts. A abundant, $\mathrm{C}$ - common, $\mathrm{R}$ - rare.

\begin{tabular}{|c|c|c|c|c|}
\hline \multirow{2}{*}{ Radiolarian taxa } & \multicolumn{4}{|c|}{ Samples } \\
\hline & $18-15-6$ & $18-15-7$ & $18-15$ & $18-16-7$ \\
\hline Bagotum maudense PESSAGNO \& WHALEN & $\mathrm{R}$ & & & \\
\hline Beatricea sp. cf. B. christovalensis WHALEN \& CARTER & $\mathrm{R}$ & & & \\
\hline Beatricea sp. & C & $\mathrm{R}$ & & $\mathrm{R}$ \\
\hline Bipedis hannai WHALEN \& CARTER & $\mathrm{R}$ & & & C \\
\hline Bipedis patricki WHALEN \& CARTER & $\mathrm{R}$ & $\mathrm{R}$ & & $\mathrm{C}$ \\
\hline Canoptum sp. cf. C. anulatum PESSAGNO \& POISSON & $\mathrm{R}$ & & & \\
\hline Canoptum sp. cf. C. artum YEH & & & & $\mathrm{R}$ \\
\hline Charlottea weedensis WHALEN \& CARTER & & & & $\mathrm{R}$ \\
\hline Gorgansium gongyloideum KISHIDA \& HISADA & A & $\mathrm{C}$ & $\mathrm{C}$ & $\mathrm{C}$ \\
\hline Gorgansium morganense PESSAGNO \& BLOME & & & & $\mathrm{R}$ \\
\hline Katroma sp. cf. K. irwingi WHALEN \& CARTER & $\mathrm{R}$ & & $\mathrm{R}$ & $\mathrm{C}$ \\
\hline Katroma ninstintsi CARTER & C & $\mathrm{R}$ & & $\mathrm{C}$ \\
\hline Lantus sp. & $\mathrm{R}$ & & & \\
\hline Pantanelluim sixi WHALEN \& CARTER & A & $\mathrm{R}$ & & $\mathrm{R}$ \\
\hline Paronaella grahamensis CARTER & $\mathrm{C}$ & & & C \\
\hline Paronaella sp. cf. P. notabilis WHALEN \& CARTER & & & & $\mathrm{R}$ \\
\hline Praehexasaturnalis tetraradiatus KOZUR \& MOSTLER & & & & $\mathrm{R}$ \\
\hline Pseudoeucyrtis busuangaensis (YEH \& CHENG) & $\mathrm{R}$ & & & $\mathrm{C}$ \\
\hline Pseudoeucyrtis sp. cf. P. busuangaensis (YEH \& CHENG) & & $\mathrm{R}$ & $\mathrm{R}$ & \\
\hline Udalia sp. cf. U. primaeva WHALEN \& CARTER & $\mathrm{R}$ & & & \\
\hline
\end{tabular}

covered from units 7 and 9 (Fig. 6) is similar (Table 1). The presence of several characteristic taxa within the radiolarian assemblages is used to determine the age of the radiolarian cherts (Fig. 9). Primary attention was given to well-preserved radiolarians determined to the species level useful for dating. Taxa described in open nomenclature are of secondary importance.

\section{Sample 18-15-6}

This sample yielded an abundant and diverse assemblage that allowed successful dating (Fig. 9, Table 1).

Bagotum maudence PESSAGNO \& WHALEN is present in the upper Sinemurian - lower Toarcian of Canada (PESSAGNO \& WHALEN, 1982; CARTER ET AL., 2010), in the lower Toarcian of Japan (YAO, 1997), and in the upper Pliensbachian of Oman (BLEICHSCHMIDT et al., 2004). The presence of this species in the upper Sinemurian is documented on Kunga Island (Haida Gwaii) in the Sinemurian part of the Sandilands Formation together with the ammonite Tetraspidoceras sp. (see fig. 3 in (CARTER et al., 2010)). The range of species according to the present data is upper Sinemurian - lower Toarcian.

Beatricea argescens (CORDEY) is known from the Pliensbachian of British Columbia, Canada (CORDEY, 1998; GORIČAN et al., 2006) and from the Lower Jurassic of Japan and New Zealand (GORIČAN et al., 2006).

Bipedis hannai WHALEN \& CARTER, 1998 is known from the lower Hettangian - lower Sinemurian of Canada (CARTER et al., 1998), from the lower Sinemurian of the Philippines (YEH \& CHENG, 1998) and from the Hettangian - Sinemurian of Turkey (TEKIN, 2002). The known range of the species is Hettangian - lower Sinemurian, but it needs additional study because it is proven by macrofossils only in Haida Gwaii, British Columbia, Canada (CARTER et al., 1998).

Bipedis japonicus GORIČAN et al., 2006 was firstly reported from the Hettangian to the Pliensbachian of Japan (HORI, 1990). It was documented later in the lower Pliensbachian of Canada (CARTER et al., 2010). Due to the absence of macrofossils in the Lower Jurassic chert sequences of Japan, we can state that the range is from the Hettangian to Pliensbachian under question.

Gorgansium gongyloideum (KISHIDA \& HISADA) is a worldwide known species with a large stratigraphic range - from the Rhaetian (Upper Triassic) to the middle Toarcian (CIFER et al., 2020; TEKIN et al., 2020).

Katroma ninstintsi CARTER is known from the Pliensbachian of Canada (CARTER et al., 1988; CARTER et al., 2010), the Philippines (YEH \& CHENG, 1998), Austria (GAWLICK et al., 2001; CIFER et al., 2020), Turkey (TEKIN, 2002), and Eastern Russia (BRAGIN \& BRAGINA, 2017).

Pantanellium sixi WHALEN \& CARTER, 1998 is known from the upper Sinemurian of Canada (CARTER et al., 1998). This species is known from only one region, and its stratigraphic range needs additional study.

Paronaella grahamensis CARTER was reported from numerous localities: from the lower Pliensbachian to the Aalenian of Canada (CARTER et al., 1988; CARTER et al., 2010), from the Pliensbachian of Mexico (WHALEN \& CARTER, 2002), Greece 
(CHIARI et al., 2013), Eastern Russia (BRAGIN \& BRAGINA, 2017), and Austria (CIFER et al., 2020). The range of this species is from the Pliensbachian to the Aalenian.

Praehexasaturnalis tetraradiatus KOZUR \& MOSTLER is present in the Hettangian of Germany (KOZUR \& MOSTLER, 1990), and Canada (CARTER et al., 1998; CARTER \& HORI, 2005; LONGRIDGE et al., 2007), the Pliensbachian of Mexico (WHALEN \& CARTER, 2002), the Hettangian to Sinemurian of Turkey (TEKIN, 2002), and the lower Pliensbachian of Austria (CIFER et al., 2020). The range is Hettangian to lower Pliensbachian.

Pseudoeucyrtis busuangaensis (YEH \& CHENG) is known from the Lower Jurassic of the Philippines (YEH \& CHENG, 1998), Japan (HORI, 2004), and Oman (BLEICHSCHMIDT et al., 2004). Recently it is documented from the lower Sinemurian - lower Pliensbachian of Turkey (TEKIN et al., 2020).

Udalia primaeva WHALEN \& CARTER, 1998 is present in the Hettangian and lower Sinemurian of Canada (CARTER et al., 1998) and from the Hettangian to the Sinemurian of Turkey (TEKIN, 2002). The range of this species needs additional study.

Certain contradictions between the stratigraphic ranges of the radiolarian taxa are observed. For example, the last appearance data of Bipedis hannai WHALEN \& CARTER is upper Sinemurian, whereas the first appearance data of Katroma ninstintsi CARTER and Paronaella grahamensis CARTER are lower Pliensbachian. The age determination of this assemblage as it is, is estimated with caution as Sinemurian-Pliensbachian.

\section{Sample 18-15-7}

This sample yielded only few taxa determined at species level (Fig. 9, Table 1). These are: Bipedis japonicus GORIČAN et al., 2006 (Hettangian? - Pliensbachian?), Gorgansium gongyloideum (KISHIDA \& HISADA) (Rhaetian - middle Toarcian), Katroma ninstintsi CARTER (Pliensbachian), and Pantanellium sixi WHALEN \& CARTER (upper Sinemurian). This poses a similar contradiction: between the ranges of Katroma ninstintsi and Pantanellium sixi. The age of the sample can be supposed to be Sinemurian - Pliensbachian.

\section{Sample 18-15-8}

Only three species are represented here, two of them were determined in open nomenclature (Fig. 9, Table 1): Gorgansium gongyloideum KISHIDA \& HISADA, Katroma sp. cf. K. irvingi WHALEN \& CARTER and Pseudoeucyrtis sp. cf. P. busuangaensis (YEH \& CHENG). Their presence confirmed the Early Jurassic age of the sample, but did not allow more detailed dating.

\section{Sample 18-16-7}

This sample yielded a diverse and moderately well-preserved assemblage which slightly differs from sample 18-15-6.

Canoptum? megathelus CORDEY is present in the Lower Jurassic of Canada (CORDEY, 1998). The stratigraphic importance of this species is poorly known.

Charlottea weedensis WHALEN \& CARTER, 1998 was previously reported from the Hettangian and lower Sinemurian of Canada (CARTER et al., 1998), from the Middle Jurassic (Bathonian) of Oregon (YEH, 2009), and from the Hettangian - Sinemurian of Turkey (TEKIN, 2002). It seems that this species has a broad stratigraphic range - from the Hettangian to the Bathonian.
Gorgansium morganense PESSAGNO \& BLOME is known from the lower Pliensbachian of British Columbia (CARTER et al., 2010) and Oregon (PESSAGNO \& BLOME, 1982; YEH, 1987). The stratigraphic range is questionable, because this species is studied only in two regions of North America.

Other species are the same as in sample 18-15-6: Bipedis hannai WHALEN \& CARTER (Hettangian - Sinemurian), Bipedis japonicus GORIČAN et al., 2006 (Hettangian? - Pliensbachian?), Gorgansium gongyloideum KISHIDA \& HISADA (Rhaetian - middle Toarcian), Katroma ninstintsi CARTER (Pliensbachian), Pantanellium sixi WHALEN \& CARTER (upper Sinemurian), Paronaella grahamensis CARTER (Pliensbachian - Aalenian), and Pseudoeucyrtis busuangaensis (YEH \& CHENG) (lower Sinemurian - lower Pliensbachian).

As a result, we have for this sample clear contradictions between the stratigraphic ranges of the determined samples. For example, the LAD of Bipedis hannai and Pantanellium sixi is the upper Sinemurian, while the FAD for Gorgansium morganense, Katroma ninstintsi, and Paronaella grahamensis is the lower Pliensbachian. The presence of such contradictions in both of the two most diverse assemblages may be explained by the insufficient current knowledge of the Lower Jurassic radiolarian stratigraphic ranges and occurrences that need more detailed study. The age of this assemblage can be estimated only with caution as a broad range - Sinemurian to Pliensbachian.

We cannot currently give a more precise age, but the presence of Lower Jurassic radiolarian chert layers in this breccia represents a significant discovery for the stratigraphy of the Dhiarizos Group, as previously a large hiatus (the Lower Jurassic and part of the Middle Jurassic) had been recorded in the typical sections of the Mamonia Complex (BRAGIN \& KRYLOV, 1996, 1999). It should be noted that the Lower Jurassic radiolarian cherts are relatively rare in the Mediterranean area (BAUMGARTNER et al., 2003; BORTOLOTTI et al., 2003; CHIARI et al., 2013). Similar rare Lower Jurassic cherts are observed as intercalations within ophiolitic breccia in the Old Zod Pass section of the Lesser Caucasus along the Armenian-Azerbaijan border zone (KNIPPER et al., 1987), and as a chert unit (Angelokastron Chert) covered by the Dhimaina and Potami formations (ophiolitic sandstones and breccias) at the Argolis in Greece (CHIARI et al., 2013). The Lower Jurassic cherts intercalated with micritic limestones were described and dated by TEKIN et al. (2020) in southeastern Turkey.

\section{THE ORIGIN AND SIGNIFICANCE OF BRECCIA}

The studied block of volcaniclastic breccia represents a new undescribed unit of the Dhiarizos Group. It differs from other units of the Dhiarizos Group by its composition and origin. The breccia consists of fragments of metabasalts, diabases and metagabbro with minor fragments of siltstones. The supporting matrix of the breccia can vary - from sandy consisting of grains of diabase and other igneous rocks to recrystallized micritic carbonates. Several beds of micritic limestone and radiolarian chert are present within the breccia. The presence of siltstone fragments and sedimentary contacts between the breccia, limestone and chert beds are an indication of the sedimentary origin of the breccia.

The volcaniclastic breccia is closely related with the volcanic units of the Dhiarizos Group, such as the Phasoula and Loutra tis Aphroditis formations, which could be the source of the clastic material. The breccia may have originated via underwater erosion of previously formed basic volcanics. The breccia is characterized by the irregular, poorly rounded character of the rock 
fragments, and by the absence of any sorting or stratification. The deposition of the breccia was probably local - along steep slopes or in narrow depressions triggered by tectonic movements. The formation of the breccia took place simultaneously with deepwater carbonate-chert sedimentation. The beds of micritic limestone and radiolarian chert within the breccia display a close affinity with the Upper Triassic - Lower Jurassic Kholetria Member of the Dhiarizos Group.

Similar Mesozoic volcaniclastic sedimentary breccias are known in various regions of the Mediterranean, either related to the upper part of plutonic and intrusive sequences of ophiolite complexes or formed within volcanic sequences (KNIPPER, 1978). The latter type is characterized by the predominance of clastic material consisting of dolerites, basalts and altered gabbro, while serpentinites are rare. These breccias can occur within or at the top of volcanic sections and they usually have sedimentary relationships with chert layers. Such breccias were studied in detail in the Ligurian Alps (GIANELLI \& PRINCIPI, 1974).

Thus, the Lower Jurassic breccia in the Akamas Peninsula represents the lower part of the Dhiarizos Group sedimentary section. The presence of radiolarian cherts related with volcaniclastic breccia is of significant interest as according to many studies the Rhaetian to Toarcian (Liassic) cherts are very rare in the Mediterranean Region, and, if present, they can be related to breccias, as in the Lesser Caucasus (KNIPPER et al., 1987) and Greece (CHIARI et al., 2013).

\section{CONCLUSIONS}

Volcaniclastic breccia of sedimentary origin, composed mainly of blocks and clasts of metabasalts, diabase and metagabbro, has been described from the Akamas Peninsula, western Cyprus.

Interbeds of radiolarian cherts within breccia yield radiolarian assemblages that allow dating of the breccia as Lower Jurassic, Sinemurian - Pliensbachian. The Triassic volcanics of the Phasoula Formation can be the source of the clastic material of the breccia.

The breccia represents a previously unknown lower part of the sedimentary cover of the Triassic volcanics (Phasoula Formation, Mamonia Complex).

\section{ACKNOWLEDGEMENTS}

This work was supported by the Russian Foundation for Basic Research, grant 19-55-25001-Cyprus_a, by the Research and Innovation Foundation of Cyprus (RIF) under the grant Bilateral/ Russia (RFBR)/1118/0025 and by Russian Governmental Assignment project 0114-2021-0003. The authors highly appreciate comments and corrections suggested by Špela Goričan and Duje Kukoč.

\section{REFERENCES}

BAUMGARTNER, P.O., BERNOULLI, D., STAMPFLI, G.M. \& CHIARI, M. (2003): Radiolarian ages, formation, and emplacement history of ophiolites in Eastern Greece. - In: INTERRAD X, Lausanne (Switzerland), abstract, 30-32.

BLEICHSCHMIDT, I., DUMITRICA, P., MATTER, A., KRYSTIN, L. \& PETERS, T. (2004): Stratigraphic architecture of the northern Oman continental margin - Mesozoic Hamrat Duru Group, Hawasina complex, Oman. - GeoArabia, 9/2, 81-132.

BLOME, C.D. \& IRWIN, W.R. (1985): Equivalent radiolarian ages from ophiolitic terranes of Cyprus and Oman. - Geology, 13/6, 401-404. doi: 10.1130/0091-7613(1985)13\%3C401:ERAFOT\%3E2.0.CO;2

BORTOLOTTI, V., CARRAS, N., CHIARI, M., FAZZUOLI, M., MARCUCCI, M., PHOTIADES, A. \& PRINCIPI, G. (2003): The Argolis peninsula in the palaeogeographic and geodynamic frame of the Hellenides. - Ofioliti, 28,79-94.

BRAGIN, N.Y. (2007): Late Triassic radiolarians of southern Cyprus. - Paleontological Journal, 41, 951-1029. doi: 10.1134/S0031030107100012
BRAGIN, N.Y. (2010): Stratigraphy of Mesozoic (Upper Triassic-Lower Cretaceous) volcanogenic-sedimentary deposits of the Dhiarizos Group, the Allochthonous Mamonia Complex of Cyprus. - Stratigraphy and Geological Correlation, 18/2, 118-132. doi: 10.1134/S0869593810020024

BRAGIN, N. \& BRAGINA, L. (2017): Early and Middle Jurassic (Pliensbachian to Bajocian) Radiolaria from cherts of Kiselevka-Manoma accretionary complex (Amur River, Eastern Russia).- Ofioliti 42: 1-19.

BRAGIN, N.Y. \& KRYLOV, K.A. (1996): Stratigraphy and lithology of the Upper Triassic deposits of southwestern Cyprus (Vlambouros Formation). - Stratigraphy and Geological Correlation, 4/2, 132-140.

BRAGIN, N.Y. \& KRYLOV, K.A. (1999): Stratigraphy and formation conditions of the Jurassic siliceous and terrigenous deposits in southwestern Cyprus.- Stratigraphy and Geological Correlation, 7/4, 333-342.

BRAGIN, N.Y., BRAGINA, L.G. \& KRYLOV, K.A. (2000): Albian-Cenomanian deposits of the Mamonia Complex, Southwestern Cyprus.- In: PANAYIDES, I., XENOPHONTHOS, C. \& MALPAS, J. (eds.): Proceedings of the Third International Conference on the Geology of the Eastern Mediterranean, Nicosia, 1998, 309-315.

BRAGINA, L.G. (2012): Radiolarian biostratigraphy of the Perapedhi Formation (Cyprus): implications for the geological evolution of the Troodos Ophiolite.- Bulletin de la Société Géologique de France, 183/4, 347-353. Doi: 10.2113/gssgfbull.183.4.343

BRAGINA, L.G. (2016): Radiolarian-based zonal scheme of the Cretaceous (AlbianSantonian) of the Tethyan regions of Eurasia.- Stratigraphy and Geological Correlation, 24/2, 141-166.

BRAGINA, L.G. \& BRAGIN, N.Y. (1996): Stratigraphy and radiolarians from the type section of Perapedhi Formation (Upper Cretaceous of Cyprus).- Stratigraphy and Geological Correlation, 4/3, 246-253.

BRAGINA, L.G. \& BRAGIN, N.Y. (2016): Cretaceous (Albian to Turonian) radiolarians from chert blocks of Moni Mélange (Southern Cyprus).- Revue de micropaléontologie, 59/4, 311-338. doi: 10.1016/j.revmic.2016.05.002

CARTER, E.S., CAMERON, B.E.B. \& SMITH P.L. (1988): Lower and Middle Jurassic radiolarian biostratigraphy and systematic, paleontology, Queen Charlotte Islands, British Columbia. - Bulletin Geological Survey Canada, 386, 1-109.

CARTER, E.S. \& HORI, R.S. (2005): Global correlation of the radiolarian faunal change across the Triassic-Jurassic boundary.- Canadian Journal of Earth Sciences, 42, 777-790. doi: 10.1139/e05-020

CARTER, E.S., WHALEN, P.A. \& GUEX, J. (1998): Biochronology and paleontology of Lower Jurassic (Hettangian and Sinemurian) radiolarians, Queen Charlotte Islands, British Columbia.- Bulletin Geological Survey Canada, 496, 1-162.

CARTER, E.S., GORIČAN, Š., GUEX, J., O'DOGHERTY, L., DE WEVER, P., DUMITRICA, P., HORI, R.S., MATSUOKA, A. \& WHALEN, P. (2010): Global radiolarian zonation for the Pliensbachian, Toarcian and Aalenian.- Palaeo., Palaeo., Palaeo., 297, 401-419. doi: 10.1016/j.palaeo.2010.08.024

CHAN, G.H.-N., MALPAS, J., XENOPHONTHOS, C. \& LO, C.-H. (2007): Timing of subduction zone metamorphism during the formation and emplacement of Troodos and Baër-Bassit ophiolites: Insights from 40Ar-39Ar geochronology.- Geological Magazine, 144, 797-810. doi: 10.1017/S0016756807003792

CHAN, G.H.-N., MALPAS, J., XENOPHONTHOS, C. \& LO, C.-H. (2008): Magmatism associated with Gondwanaland rifting and Neo-Tethyan oceanic basin development: evidence from the Mamonia Complex, SW Cyprus.- Journal of the Geological Society, 165, 699-709. doi: 10.1144/0016-76492007-050

CHIARI, M., BAUMGARTNER, P.O., BERNOULLI, D., BORTOLOTTI, V., MARCUCCI, M., PHOTIADES, A. \& PRINCIPI, G. (2013): Late Triassic, Early and Middle Jurassic radiolaria from ferromanganese-chert “nodules” (Angelokastron, Argolis, Greece): evidence for prolonged radiolarite sedimentation in the MaliacVardar Ocean.- Facies, 59, 391-424. doi: 10.1007/s10347-012-0314-4

CIFER, T., GORIČAN, Š., GAWLICK, H.-J., AUER, M. (2020): Pliensbachian, Early Jurassic radiolarians from Mount Rettenstein in the Northern Calcareous Alps, Austria.- Acta Palaeontologica Polonica, 65/1, 167-207. doi: 10.4202/ app.00618.2019

CORDEY, F. (1998): Radiolaires des complexes d'accrétion de la Cordillére Canadienne (Colombie-Britannique).- Commission Géologique du Canada, Bulletin 509, 1-209.

GASS, I.G. (1960): The petrography, structure and evolution of the Troodos Massif, Cyprus.- (Unpubl. PhD thesis) - University of Leeds, 279 p.

GAWLICK, H.-J., SUZUKI, H. \& MISSONI, S. (2001): Nachweis von unterliassischen Beckensedimenten in Hallstätter Fazies (Dürnberg-Formation) im Bereich der Hallein-Berchtesgadener Hallstätter Zone und des Lammer Beckens (HettangiumSinemurium).- Mitteilungen Ges. Geol. Bergbaustud Österr., 45, 39-55.

GEOLOGICAL SURVEY DEPARTMENT OF CYPRUS (2008): Geological map of Paphos-Kallepeia area. Nicosia, sheet 16 III-IV. Scale 1:25000.

GEOLOGICAL SURVEY DEPARTMENT OF CYPRUS (2015): Geological map of the Pegeia-Steni area. Nicosia, sheet 16 I-II. Scale 1:25000. 
GIANELLI, G. \& PRINCIPI, G. (1974): Studies on mafic and ultramafic rocks. 4. Breccias of the ophiolitic suite in the Monto Bocco area (Ligurian Apennine). - Bolletino Societa Geologica Italiana, 93, 277-308.

GORIČAN, Š., CARTER, E.S., DUMITRICA, P., WHALEN, P.A., HORI, R.S., DE WEVER, P., O'DOGHERTY, L., MATSUOKA, A. \& GUEX, J. (2006): Catalogue and Systematics of Pliensbachian, Toarcian and Aalenian Radiolarian Genera and Species.-ZRC Publishing, Scientific Research Centre of the Slovenian Academy of Sciences and Arts, Ljubljana, $446 \mathrm{p}$.

HENSON, F.R.S., BROWNE, R.V. \& MCGINTY, J. (1949): A synopsis of the stratigraphy and geological history of Cyprus.- Quarterly Journal of the Geological Society of London, 105, 1-41. doi: 10.1144/GSL.JGS.1949.105.01-04.03

HORI, R. (1990): Lower Jurassic radiolarian zones of SW Japan.- Trans. Proc. Palaeont. Soc. Japan, N. S., 159, 562-586.

HORI, N. (2004): Jurassic radiolarians from chert and clastic rocks of the Chichibu Belt in the Toyohashi district, Aichi Prefecture, Southwest Japan.- Bulletin of the Geological Survey of Japan, 55, 335-388.

KNIPPER, A.L. (1978): Ophicalcites and some other types of breccia accompanying pre-orogenic formation of ophiolite assemblage. - Geotectonics, 2, 50-66 (in Russian).

KNIPPER, A.L., SATIAN, M.A. \& BRAGIN, N.Y. (1997): Upper Triassic-Lower Jurassic volcanogenic and sedimentary deposits of the Old Zod Pass (Transcaucasia). - Stratigraphy, Geological Correlation, 3, 58-65. (in Russian).

KOZUR, H. \& MOSTLER, H. (1990): Saturnaliacea DEFLANDRE and some other stratigraphically important radiolaria from the Hettangian of Lenggries/Isar (Bavaria, Northern Calcareous Alps). - Geol. Paläontol. Mitt. Innsbruck, 17, 179-248.

LAPIERRE, H. (1975): Les formations sédimentaires et éruptives des nappes de Mamonia et leurs relations avec le Massif du Troodos.- Mémoires de la Société Géologique de France, 123, $127 \mathrm{p}$.

LONGRIDGE, L.M., CARTER, E.S., SMITH, P.L., \& TIPPER, H.W. (2007): Early Hettangian ammonites and radiolarians from the Queen Charlotte Islands, British Columbia and their bearing on the definition of the Triassic-Jurassic boundary.- $\mathrm{Pa}-$ laeogeography, Palaeoclimatology, Palaeoecology, 244, 142-169. doi: 10.1016/j. palaeo.2006.06.027

MALPAS, J., XENOPHONTHOS, C. \& WILLIAMS, D. (1992): The Ayia Varvara Formation of SW Cyprus: a product of complex collisional tectonics. - Tectonophysics, 212, 193-211. doi: 10.1016/0040-1951(92)90291-D

MARTINI, R., PEYBERNÉS, B. \& MOIX, P. (2009): Late Triassic foraminifera in reefal limestones of SW Cyprus. - Journal of Foraminiferal Research, 39/3, 218-230. doi: 10.2113/gsjfr.39.3.218

PESSAGNO JR., E.A. \& WHALEN, P.A. (1982): Lower and Middle Jurassic Radiolaria (multicyrtid Nassellariina) from California, east-central Oregon and the Queen Charlotte Islands, B.C.- Micropaleontology, 28, 111-169. doi: $10.2307 / 1485228$
ROBERTSON, A.H.F. (1977): The Kannaviou Formation, Cyprus: volcaniclastic sedimentation of a probable Late Cretaceous volcanic arc.- Journal of the Geological Society London, 134/3, 269-292. doi: 10.1144/gsjgs.134.3.0269

ROBERTSON, A.H.F. \& HUDSON, J.D. (1974): Pelagic sediments in the Cretaceous and Tertiary history of Cyprus.- In: HSU, K.J. \& JENKYNS, H.C. (eds.): Pelagic Sediments: On Land and Under the Sea.- Special Publications International Association Sedimentologists, 1, 403-436.

ROBERTSON, A.H.F. \& WOODCOCK, N.H. (1979): Mamonia Complex, Southwest Cyprus: Evolution and Emplacement of a Mesozoic Continental Margin.- Bull. Geol. Soc. of America, 1/9, 651-665. doi: 10.1130/0016-7606(1979)90\%3C651: MCSCEA\%3E2.0.CO;2

SWARBRICK, R.E. \& ROBERTSON, A.H.F. (1980): Revised stratigraphy of the Mesozoic rocks of southern Cyprus.- Geological Magazine, 117/5, 547-563. doi: 10.1017/S0016756800028892

TEKIN, U.K. (2002): Lower Jurassic (Hettangian-Sinemurian) radiolarians from the Antalya Nappes, Central Taurids, Southern Turkey.- Micropaleontology, 48/2, 177-205. doi: 10.2113/48.2.177

TEKIN, U.K., KRYSTYN, L., OKUYUCU, C., BEDI, Y., SAYIT, K. (2020): Late Triassic to Early Jurassic radiolarian, conodont and ammonite assemblages from the Tavuscayiri block, Mersin Mélange, southern Turkey: Time constraints for the T/J boundary and sedimentary evolution of the southern margin of the northern Neotethys. - Geodiversitas, 42/27, 493-537. doi: 10.5252/geodiversitas2020v42a27

TORLEY, J.M. \& ROBERTSON, A.H.F. (2018): New evidence and interpretation of facies, provenance and geochemistry of late Triassic-early Cretaceous Tethyan deep-water passive margin-related sedimentary rocks (Ayios Photios Group), SW Cyprus in the context of eastern Mediterranean geodynamics.- Sedimentary Geology, 377, 82-110. doi: 10.1016/j.sedgeo.2018.09.001

WHALEN, P.A. \& CARTER, E.S. (1998): Systematic Paleontology.-In: CARTER, E.S., WHALEN, P.A. \& GUEX, J. (1998): Biochronology and paleontology of Lower Jurassic (Hettangian and Sinemurian) Radiolarians, Queen Charlotte Islands, British Columbia. Geological Survey of Canada Bulletin, 496, 1-147.

WHALEN, P.A. \& CARTER, E.S. (2002): Pliensbachian (Lower Jurassic) radiolaria from Baja California Sur, Mexico.- Micropaleontology 48/2, 97-151. doi: 10.2113/48.2.97

WILSON, R.A.M. (1959): The geology and mineral resources of the Xeros-Troodos Area.- Memoirs Geological Survey Cyprus 1, 1-136.

YAO, A. (1997): Faunal change of Early-Middle Jurassic radiolarians. - News of Osaka Micropaleontologists, Spec. Vol. 10, 155-182.

YEH, K.-Y. (1987): Taxonomic studies of Lower Jurassic Radiolaria from east-central Oregon.- National Museum of Natural Science, Special Publication 2, 1-169.

YEH K.-Y. (2009): A Middle Jurassic radiolarian fauna from Southfork member of Snowshoe Formation, east-Central Oregon.- Collection and Research 22, 15-125.

YEH, K.-Y. \& CHENG, Y.-N. (1998): Radiolarians from the Lower Jurassic of the Busuanga Island, Philippines.- Bull. Nat. Mus. Nat. Sci. (Taiwan) 11, 1-65. 




Plate 1. Lower Jurassic Radiolaria (Spumellaria)

A, B - Pantanellium sixi WHALEN \& CARTER; C, D - Gorgansium gongyloideum KISHIDA \& HISADA; E - Gorgansium morganense PESSAGNO \& BLOME; F - Charlottea weedensis WHALEN \& CARTER; G - Paronaella grahamensis CARTER; H - Praehexasaturnalis tetraradiatus KOZUR \& MOSTLER; I - Beatricea? argescens (CORDEY); J - Paronaella sp. cf. P. notabilis WHALEN \& CARTER; K - Udalia primaeva WHALEN \& CARTER; L, M - Udalia spp.

Magnification - 1-5, 8 - 1; 6, 7, 9-13 - 2. Scale $100 \mu$ m. Figs. A, B, C, G, I, K, L, M - sample 18-15-6; figs. D, E, F, H, J - sample 18-16-7 

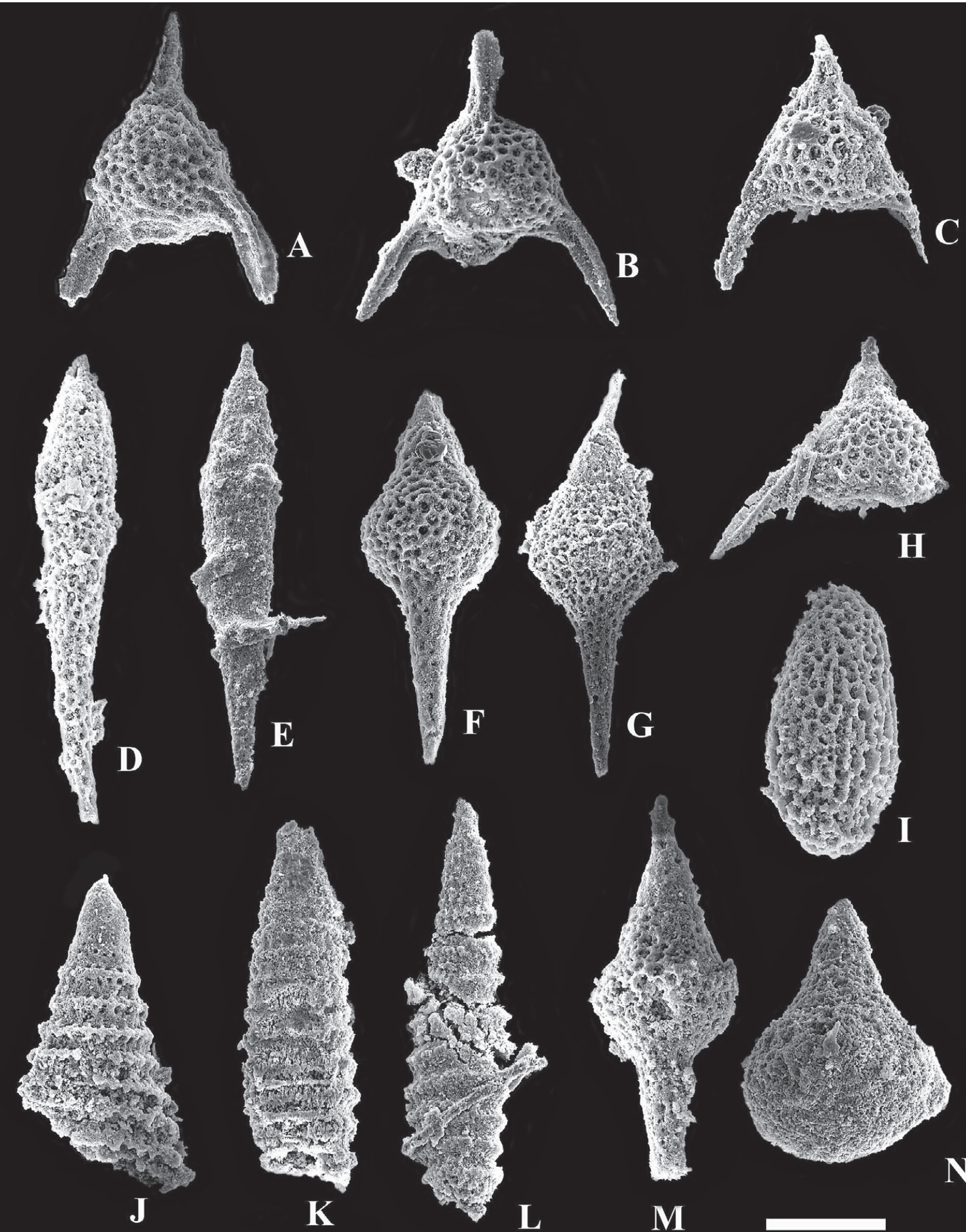

M

Plate 2. Lower Jurassic Radiolaria (Nassellaria)

A, B - Bipedis japonicus HORI; C, H - Bipedis hannai WHALEN \& CARTER; D - Pseudoeucyrtis busuangaensis (YEH \& CHENG); E - Pseudoeucyrtis sp. cf. P. busuangaensis (YEH \& CHENG); F, G - Katroma ninstintsi CARTER; I - Bagotum maudense PESSAGNO \& WHALEN; J - Canoptum? megathelus CORDEY; K, L - Canoptum sp. cf. C. anulatum PESSAGNO \& POISSON; M - Katroma sp. cf. K. irvingi WHALEN \& CARTER; $\mathbf{N}$ - Lantus sp. cf. L. obesus (YEH). Scale 100 um. Figs. A, B, F, I, K, L, N - sample 18-15-6, fig. E - sample 18-15-8; figs. C, D, G, H, J, M - sample 18-16-7 